\title{
REGIONAL DIFFERENCES OF BREAST CANCER RISK FACTORS IN NEWLY DIAGNOSED FEMALE PATIENTS IN CROATIA
}

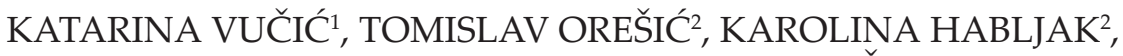 \\ MARIJA KAHLINA ${ }^{2}$, IVA KIRAC ${ }^{2}$ and MARIO ŠEKERIJA ${ }^{3}$ \\ ${ }^{1}$ Department for Safety and Efficacy Assessment of Medicinal Products, \\ Agency for Medicinal Products and Medical Devices, Zagreb, Croatia; \\ ${ }^{2}$ Department of Surgical Oncology, University Hospital for Tumors, \\ Sestre milosrdnice University Hospital Center, Zagreb, Croatia; \\ ${ }^{3}$ Croatian National Cancer Registry, Department for Malignant Diseases, \\ Croatian Institute of Public Health, Zagreb and Andrija Štampar School of Public Health, \\ University of Zagreb School of Medicine, Zagreb, Croatia
}

\begin{abstract}
Summary
Background: Presence of breast cancer environmental risk factors may vary between the regions and settlement of residence size depending on the differences in lifestyle and level of specific exposures. Genetic risk factors could also show differences between regions. The aim of this cross-sectional study was to explore regional differences in breast cancer risk factors pertaining to the environment and genetics in medical history of newly diagnosed female patients in Croatia.

Methods: We surveyed 203 women with newly diagnosed, previously untreated breast cancer (BCa) from all parts of Croatia, hospitalized consecutively between December 2016 and August 2017, for known BCa risk factors using the self-administered questionnaire. Data were analyzed separately by two main Croatian regions (continental, Mediterranean) and settlement of current residence size (urban, semi-urban/rural), as defined by Croatian Bureau of Statistics.

Results: Women living in urban settlements were more often nulliparous or had their first child at an older age, had higher education level, lower number of children, more often consumed alcohol and were obese compared to those from semi-urban/rural areas. Women living in continental part of the country more often breast fed shorter. Several of the differences were also found between premenopausal and postmenopausal women.

Conclusion: In total breast cancer population, we noticed several regional and urban BCa risk factor variations characteristical for lifestyle differences.
\end{abstract}

KEY WORDS: breast cancer, risk factors, environmental, genetic, Croatia, regions

\section{REGIONALNE RAZLIKE U FAKTORIMA RIZIKA NOVOOBOLJELIH PACIJENTICA OD RAKA DOJKE U HRVATSKOJ}

\section{Sažetak}

Uvod: Prisutnost vanjskih rizičnih faktora za rak dojke može varirati između regija i veličine naselja u kojima žena živi, ovisno o razlikama u načinu života i razini specifičnih izloženosti. Genetski rizični faktori također mogu pokazivati razlike između regija. Cilj ovog presječnog istraživanja bio je istražiti regionalne razlike u vanjskim i genetskim rizičnim faktorima raka dojke u anamnezi žena s novootkrivenim rakom dojke u Hrvatskoj.

Metode: Poznati rizični faktori raka dojke ispitani su samoispunjavanjem upitnika kod 203 novodijagnosticirane prethodno neliječene žene koje su konsekutivno hospitalizirane između prosinca 2016 i kolovoza 2017. Podaci su analizirani 
prema dvije glavne regije Hrvatske (kontinentalna, mediteranska) i veličini naselja (urbana, semi-urbana/ruralna) trenutnog prebivanja, definiranih prema Državnom zavodu za statistiku.

Rezultati: Žene koje prebivaju u urbanim naseljima češće nisu rađale ili su imale prvo dijete u starijoj dobi, višu razinu edukacije, manji broj djece, češće su konzumirale alkohol i bile pretile u usporedbi s ženama iz semi-urbanih/ruralnih područja. Žene koje prebivaju u kontinentalnom dijelu zemlje češće su kraće dojile. Pojedine od navedenih razlika su nađene i između premenopauzalnih i postmenopauzalnih žena.

Zaključak: U ukupnom uzorku bolesnica s rakom dojke, za rizične faktore je opaženo nekoliko regionalnih i razlika prema veličini naselja karakterističnih za razlike u načinu života.

KLJUČNE RIJEČI: rak dojke, faktori rizika, okolišni, genetski, Hrvatska, regije

\section{INTRODUCTION}

Breast cancer shows an increasing trend in Croatia with estimated annual percent of change of $2.6 \%$ (1). According to the International Agency for Research on Cancer (IARC), carcinogenic agents with sufficient evidence in humans for breast cancer (2) are alcoholic beverages (3), diethylstilbestrol, estrogen-progestogen contraceptives, estrogen-progestogen menopausal therapy (4), X-radiation and gamma-radiation (5). IARC classified additional agents with carcinogenic effects but with limited evidence in humans for breast cancer (BCa) to be digoxin, estrogen menopausal therapy, ethylene oxide, polychlorinated biphenyls (6), shiftwork that involves circadian disruption (7), and tobacco smoking (8). Beside exogenous exposure to estrogens in form of the pharmaceuticals, endogenous prolonged exposure to increased levels of estrogens in the cases of early menarche and late menopause are also considered to increase risk for developing $\mathrm{BCa}$, as well as behavioral factors such as increased body weight in older age, being nulliparous or having the first child at an older age (9). Presence of breast cancer environmental and genetic risk factors may vary between the Croatian regions and settlement of residence size based on the differences in lifestyle, level of specific exposures and inherited and additionally acquired mutations predisposing to breast cancer development. Such regional differences in Croatia were shown for example for IARC BCa classified agents such as alcohol consumption and smoking, and for some other known behavioral BCa risk factors (10) e.g. obesity, physical activity, diet (11). Urban-rural differences in terms of pregnancies were also shown in women participating in the Croatian population-based $\mathrm{BCa}$ screening program (12). We sought to explore presence of breast cancer risk factors pertaining to the environmen- tal and genetics in medical history of newly diagnosed female patients in Croatia, and to describe their regional differences.

\section{PATIENTS AND METHODS}

We surveyed 203 adult women from all parts of Croatia with newly diagnosed previously untreated breast cancer hospitalized consecutively between December 2016 and August 2017. Medical history data on known BCa risk factors were collected before treatment at two surgical oncology departments of the University Hospital for Tumors, Zagreb, Croatia, using the self-administered questionnaire. Surveyed patients constituted representative sample in terms of number of new cases in Croatia ( $8 \%$ ) (13) per year, and size of region/settlement of their residence. This academic study was approved by the ethics committees of Sestre milosrdnice University Hospital Center and School of Medicine, University of Zagreb, and conducted in accordance to the Principles of Helsinki Declaration. The environmental BCa risk factors questions included reproductive and gynecological history (births, breastfeeding, menarche, menopause), medications (contraception, hormone replacement therapy, other), alcohol consumption (categorizing heavy/moderate consumption as daily/few times a week), chest radiation (more than 10 times in life), smoking (previous/current), night shifts work (any time in life and of any duration), education level (higher than high school), physical activity, diet, place of living. Perimenopausal status was defined if women declared to be in a menopause for less than 1 year. Genetic BCa risk factors questions included personal and family history of breast, ovarian, uterus and any other cancers, including benign disorders. Body mass index $\left(\mathrm{kg} / \mathrm{m}^{2}\right)$ was 
Lib Oncol. 2018;46(2-3):47-54

Table 1.

MEDICAL HISTORY AND BREAST CANCER RISK FACTORS BY MENOPAUSAL STATUS

\begin{tabular}{|c|c|c|c|c|}
\hline $\begin{array}{l}\text { Characteristics } \\
\text { (\# unknown) }\end{array}$ & \begin{tabular}{|l|} 
Total \\
$\mathrm{n}(\%)$
\end{tabular} & \begin{tabular}{|l|} 
Pre-/peri- \\
menopause
\end{tabular} & \begin{tabular}{|l|} 
Post- \\
menopause
\end{tabular} & P-value \\
\hline Number of patients & $n=203$ & $n=70(55+15)$ & $n=133$ & \\
\hline Age (years), median (range) & $59(28-87)$ & $44(28-55)$ & $65(47-87)$ & $<0.001$ \\
\hline $\begin{array}{r}0 \\
1 \\
2 \\
3 \text { or } 4\end{array}$ & $\begin{array}{l}16(7.9) \\
97(47.8) \\
77(37.9) \\
13(6.4)\end{array}$ & $\begin{array}{l}7(10) \\
33(47.1) \\
28(40) \\
2(2.9)\end{array}$ & \begin{tabular}{|l}
$9(6.8)$ \\
$64(48.1)$ \\
$49(36.8)$ \\
$11(8.3)$
\end{tabular} & 0.417 \\
\hline Hormone replacement therapy $\geq 5$ years: & $\begin{array}{l}19^{*}(9.4) \\
184(90.6)\end{array}$ & - & $\begin{array}{l}19^{*}(14.3) \\
114(84.2)\end{array}$ & - \\
\hline Contraception $\geq 5$ years: & $\begin{array}{l}18(8.9) \\
185(91.1)\end{array}$ & $\begin{array}{l}8(11.4) \\
62(88.6)\end{array}$ & $\begin{array}{l}10(7.5) \\
123(92.5)\end{array}$ & 0.351 \\
\hline Early menarche $(<12 \mathrm{y}$.): & $\begin{array}{l}23(11.4) \\
180(88.7)\end{array}$ & $\begin{array}{l}8(11.4) \\
62(88.6)\end{array}$ & $\begin{array}{l}15(11.3) \\
118(88.7)\end{array}$ & 0.974 \\
\hline Late menopause (>55 y.): & \begin{tabular}{|l|}
$5(2.5)$ \\
$197(97)$
\end{tabular} & - & \begin{tabular}{|l|}
$5(3.8)$ \\
$127(95.5)$
\end{tabular} & - \\
\hline Nulliparous or 1 st child after $30:$ & \begin{tabular}{|l|}
$49(24.1)$ \\
$154(75.9)$
\end{tabular} & $\begin{array}{l}25(35.7) \\
45(64.3)\end{array}$ & \begin{tabular}{|l|}
$24(18)$ \\
$109(82)$
\end{tabular} & 0.005 \\
\hline Breastfeeding < 12 months: & $\begin{array}{l}155(76.4) \\
48(23.6)\end{array}$ & $\begin{array}{l}46(65.7) \\
24(34.3)\end{array}$ & $\begin{array}{l}109(82) \\
24(18)\end{array}$ & 0.009 \\
\hline Smoking (previous or current): & $\begin{array}{l}105(51.7) \\
98(48.3)\end{array}$ & $\begin{array}{l}42(60) \\
28(40)\end{array}$ & $\begin{array}{l}63(47.4) \\
70(52.6)\end{array}$ & 0.086 \\
\hline $\begin{array}{r}\text { yes } \\
(\# 10) \text { no }\end{array}$ & \begin{tabular}{|l|}
$31(15.3)$ \\
$172(84.7)$
\end{tabular} & $\begin{array}{l}11(15.7) \\
59(84.3)\end{array}$ & \begin{tabular}{|l|}
$20(15)$ \\
$113(85)$
\end{tabular} & 0.898 \\
\hline 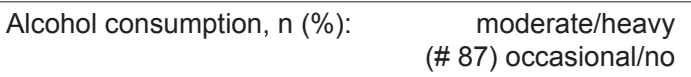 & $\begin{array}{l}27(13.3) \\
176(86.7)\end{array}$ & $\begin{array}{l}9(12.9) \\
61(87.1)\end{array}$ & $\begin{array}{l}18(13.5) \\
115(86.5)\end{array}$ & 0.892 \\
\hline Obesity $\left(\mathrm{BMI}, \mathrm{kg} / \mathrm{m}^{2}\right), \mathrm{n}(\%)$ : & $\begin{array}{l}42(20.7) \\
161(79.3)\end{array}$ & $\begin{array}{l}5(7.1) \\
65(92.8)\end{array}$ & $\begin{array}{l}37(27.8) \\
96(72.2)\end{array}$ & $<0.001$ \\
\hline Higher education (>high school): & $\begin{array}{l}75(36.9) \\
128(63.1)\end{array}$ & $\begin{array}{l}36(51.4) \\
34(48.6)\end{array}$ & $\begin{array}{l}28(21.1) \\
105(78.9)\end{array}$ & $<0.001$ \\
\hline$>10$ chest radiologic imaging: & $\begin{array}{l}47(23.2) \\
156(76.8)\end{array}$ & $\begin{array}{l}3(4.3) \\
67(95.7)\end{array}$ & $\begin{array}{l}44(32.6) \\
89(66.9)\end{array}$ & $<0.001$ \\
\hline Breast or ovary cancer in relatives ${ }^{* *}$ : & $\begin{array}{l}66(32.5) \\
137(67.5)\end{array}$ & $\begin{array}{l}27(38.6) \\
43(60.4)\end{array}$ & $\begin{array}{l}40(30.1) \\
93(69.9)\end{array}$ & 0.221 \\
\hline Other breast cancers $\$$ & $1(0.5)$ & 0 & $1(0.8)$ & - \\
\hline Breast benign lesions $\$$ (yes/no) & $12(5.9) / 191$ & $2(2.9) / 68$ & $10(7.5) / 123$ & 0.225 \\
\hline Gynecological cancers $\$ \$$ & $3(1.5)$ & $1(1.4)$ & $2(1.5)$ & - \\
\hline Gynecological benign lesions $\$ \$$ & $54(26.6)$ & $18(25.7)$ & $35(26.3)$ & 0.926 \\
\hline Other cancers§ & $5(2.5)$ & $1(1.4)$ & $4(3)$ & - \\
\hline Other benign lesions§ (yes/no) & $13(6.4) / 190$ & $2(2.9) / 68$ & $11(8.3) / 122$ & 0.226 \\
\hline Other cancers in relativesł: & $\begin{array}{l}126(62.1) \\
78(38.4)\end{array}$ & $\begin{array}{l}48(68.6) \\
22(31.4)\end{array}$ & $\begin{array}{l}78(58.4) \\
56(42.1)\end{array}$ & 0.148 \\
\hline Urban settlements: & $\begin{array}{l}150(73.9) \\
53(26.1) \\
\end{array}$ & $\begin{array}{l}51(72.3) \\
19(27.7)\end{array}$ & $\begin{array}{l}99(74.4) \\
34(25.6)\end{array}$ & 0.807 \\
\hline $\begin{array}{r}\text { Continental } \\
\text { Mediterranean }\end{array}$ & $\begin{array}{l}182(89.7) \\
21(10.3)\end{array}$ & $\begin{array}{l}60(85.7) \\
10(14.3)\end{array}$ & $\begin{array}{l}122(91.7) \\
11(8.3)\end{array}$ & 0.181 \\
\hline
\end{tabular}

\# Number of patients with no response to questions; * Including 3 women with HRT use $<5 \mathrm{y}$. but with $\geq 5$ years total use of both HRT and contraception; ** Mother, sisters, grandmothers, cousins; ${ }^{\$}$ Cancers: breast cancer (not confirmed in medical records); benign: fibroadenomas, breast biopsy, breast operation, benign breast tumor, breast cyst, sclerosing adenosis; ${ }^{\$}$ Cancers: cervical cancer, ovary cancer (both not confirmed in medical records); benign: conisation, uterine polyps, lifting of uterus, operation of uterus and/or ovary, removal of uterus and/or ovary, operation of cervix uteri, mioma uteri, ovarian cystadenoma, ovarian cyst, ovarian mioma, cervical polyp, endometriosis, gynecologic operation, Barth. gland operation, ovarian tube cystitis, preeclampsia, benign tumor of vulvae, curettage; § Cancers: bronchial, bladder, facial skin, melanoma; benign lesions: polyp colony, pyelon papilloma, glomus tumor of finger, unspecified polyp, nasal polyps, unspecified mioma, unspecified tumor surgery 5 decades ago, neck lipoma, surgery of thyroid gland, salivary gland cyst, both suprarenal gland adenomas, ulcerative colitis; $\ddagger$ Parents, sisters/brothers, grandparents, other relatives 
calculated from weight $(\mathrm{kg})$ and height $(\mathrm{cm})$ data measured on first day of hospitalization. Data were analyzed separately by two main Croatian regions (continental, Mediterranean) and size of settlement (urban, semi-urban/rural) of their current residence, as defined by the Croatian Bureau of Statistics (CBS). Thus, the continental Croatia was defined to encompass the regions of Central Croatia and Slavonia, and the Mediterranean Croatia referred to Istria and Gorski kotar, Dalmatia and Lika (14). According to the CBS, urban settlements (15) were defined as having $\geq 10,000$ inhabitants (using 2011 Census data (16)), and semi-urban/rural as having $<10,000$ inhabitants. Questions with no response were analyzed as no threshold exposure, and for HRT or contraception if information on use was provided without duration of use, this was analyzed as use $<1$ year, including for any duration of herbal postmenopause remedies.

Beside descriptive statistics by menopausal status, including data for regions and urban settlements, statistical comparison was performed by software available online (17) defining statistically significant $P$-values as $<0.05$. For data presented as $\mathrm{n}(\%)$ chi-square test was used, for $\mathrm{n}<5(\%)$ data Fisher exact test, and for continuous data twotailed Mann-Whitney test. Calculations were performed on 24th and 25th November 2018.

\section{RESULTS}

Two thirds of 203 included women with BCa were diagnosed in menopause, and there were no differences in proportion of pre-/perimenopausal and postmenopausal women living in urban and continental part of Croatia; patients living in these areas constituted the majority of the studied population (Table 1). Patients from the City of Zagreb constituted the majority $(65.5 \%)$ of the study population. Median age of women from the continental region was significantly higher $(\mathrm{P}=0.004)$ than of those from the Mediterranean region (60 vs 49, respectively). Premenopausal women as well as patients living in urban settlements were more often nulliparous or had their first child at an older age, and had higher education level, compared to the patients living in semi-urban/rural areas, whilst postmenopausal women were often obese and had more chest radiologic imaging. Women living in the continental part of the country rarely had late menopause ( $>55$ years) and, as well as postmenopausal women in general, more frequently breast fed shorter. Higher proportion of patients from urban continental settlements seemed to have used HRT and contraception, and compared to the Mediterranean area worked in night shifts, were diagnosed in earlier stage of BCa (majority at stages 0 and 1 ) and had breast or ovary cancer in their relatives (Table 2), but without reaching statistical significance in this sample size.

\section{DISCUSSION}

Our study investigated regional and urban/ rural differences in Croatia regarding the distribution of $\mathrm{BCa}$ risk factors among women with newly diagnosed BCa. We found some environmental factors differences between pre-/perimenopausal and postmenopausal women, as well as between women living in urban and semi-urban/rural settlements related to the lifestyle differences in terms of number of children, age of the first birth, level of education. These findings are consistent with the previous study investigating the urbanrural differences in women participating in the Croatian population-based $\mathrm{BCa}$ screening program (12). Although risk of BCa is minimized after 10 years of estrogen medication administration stopping (18), in few women using HRT for $<5$ years but also previously using contraception, this was analyzed as positive exposure if total use of both was reported $\geq 5$ years. Since no response was given regarding time elapsed between usage of these two medications and considering risk depends on age at last use of contraceptives and high number of no response to questions on usage (or its length) of both HRT and contraceptives, possibility of result for continental urban area to become significant cannot be excluded. In addition to exogenous estrogens in form of medications (4), prolonged exposure to higher levels of endogenous estrogens is also associated with increased risks of BCa in both premenopausal (19) and postmenopausal (20) women with the highest risk in women with the highest level of estradiol. It is estimated that for every year of earlier menarche risk rise by $4 \%$, per year of late age at menopause by $3 \%$, whilst relative risk decreases by about $3 \%$ for every year women is younger when giving 
Lib Oncol. 2018;46(2-3):47-54

Table 2.

REGIONAL DISTRIBUTION OF BCA RISK FACTORS BY CROATIAN REGIONS AND SETTLEMENTS SIZE

\begin{tabular}{|c|c|c|c|c|c|c|c|c|}
\hline & $\begin{array}{r}\text { Continer } \\
\text { settle }\end{array}$ & $\begin{array}{l}\text { ntal area } \\
\text { ments }\end{array}$ & P-value & $\begin{array}{r}\text { Mediterr } \\
\text { settl }\end{array}$ & $\begin{array}{l}\text { anean area } \\
\text { ements }\end{array}$ & P-value & P-value & P-value \\
\hline Characteristics" & Urban"\# & Semi-U/Rural & & Urban & Semi-U/Rural & & Area & Settl. \\
\hline Number of patients, n (\%): & $139(68.5)$ & $43(21.2)$ & & $11(5.4)$ & $10(4.9)$ & & $182+21$ & $150+53$ \\
\hline Age (years), median (range) & $61(28-87)$ & $57(35-85)$ & 0.833 & $45(37-66)$ & $52.5(31-64)$ & 0.342 & 0.004 & 0.703 \\
\hline $\begin{array}{r}\text { Menopausal status, } \mathrm{n}(\%) \text { : } \\
\text { Pre-/perimenopause } \\
\text { Postmenopause }\end{array}$ & $\begin{array}{l}45(32.4) \\
94(67.6)\end{array}$ & $\begin{array}{l}15(34.9) \\
28(65.1)\end{array}$ & 0.759 & $\begin{array}{l}6(54.5) \\
5(45.5)\end{array}$ & $\begin{array}{l}4(40) \\
6(60)\end{array}$ & 0.669 & 0.181 & 0.807 \\
\hline TNM stage, n (\%): & $\begin{array}{l}78(56.1) \\
61(43.9)\end{array}$ & $\begin{array}{l}27(62.8) \\
16(37.2)\end{array}$ & 0.540 & $\begin{array}{l}5(45.5) \\
6(54.5)\end{array}$ & $\begin{array}{l}3(30) \\
7(70)\end{array}$ & 0.659 & 0.086 & 0.872 \\
\hline HRT (years), n (\%): & $\begin{array}{l}17^{*}(13.7) \\
122(86.3)\end{array}$ & $\begin{array}{l}1(2.3) \\
42(97.7)\end{array}$ & 0.077 & \begin{tabular}{|l|}
0 \\
$11(100)$
\end{tabular} & $\begin{array}{l}1(10) \\
9(90)\end{array}$ & 0.476 & 0.699 & 0.167 \\
\hline $\begin{array}{rr}\text { Contraception (years), n (\%): } & \geq 5 \\
(\# 17) & 0-<5\end{array}$ & $\begin{array}{l}13(9.4) \\
126(91.6)\end{array}$ & $\begin{array}{l}2(4.7) \\
41(95.3)\end{array}$ & 0.527 & $\begin{array}{l}2(18.2) \\
9(81.8)\end{array}$ & $\begin{array}{l}1(10) \\
9(90)\end{array}$ & 1 & 0.408 & 0.473 \\
\hline 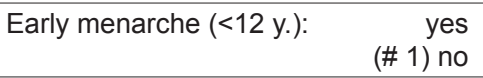 & \begin{tabular}{|l|}
$19(13.7)$ \\
$120(86.3)$
\end{tabular} & $\begin{array}{l}2(4.7) \\
41(95.3)\end{array}$ & 0.105 & $\begin{array}{l}1(9.1) \\
10\end{array}$ & $\begin{array}{l}1(10) \\
9(90)\end{array}$ & 1 & 1 & 0.206 \\
\hline $\begin{array}{ll}\text { Late menopause (years), } \mathrm{n}(\%): & >55 \\
& \leq 55\end{array}$ & \begin{tabular}{|l|}
$2(1.4)$ \\
$137(98.6)$ \\
\end{tabular} & $\begin{array}{l}2(4.7) \\
41(95.4)\end{array}$ & 0.237 & $\begin{array}{l}1(9.1) \\
10(90.9) \\
\end{array}$ & $\begin{array}{l}2(20) \\
8(80) \\
\end{array}$ & 0.587 & 0.026 & 0.078 \\
\hline $\begin{array}{r}\text { Nulliparous or } 1 \text { st child after } 30 \text { y.: yes } \\
\text { no }\end{array}$ & $\begin{array}{l}43(30.9) \\
96(69.1)\end{array}$ & $\begin{array}{l}3(7) \\
40(93)\end{array}$ & 0.001 & $\begin{array}{l}2(18.2) \\
9(81.8)\end{array}$ & $\begin{array}{l}1(10) \\
9(90)\end{array}$ & 1 & 0.419 & $<0.05$ \\
\hline $\begin{array}{l}\text { Number of children, } \\
\text { median (range) (\#4) }\end{array}$ & $2(0-4)$ & $2(0-4)$ & 0.023 & $2(0-3)$ & $2(0-3)$ & 0.384 & 0.327 & 0.010 \\
\hline $\begin{array}{l}\text { Age at first birth (years), } \\
\text { median (range) (\#3) }\end{array}$ & $25(17-39)$ & $22(18-38)$ & 0.015 & $\begin{array}{l}24.5 \\
(18-35.5)\end{array}$ & $21(18-28)$ & 0.177 & 0.417 & 0.003 \\
\hline Breastfeeding $<12$ months: & $\begin{array}{l}112(80.6) \\
27(19.4)\end{array}$ & $\begin{array}{l}32(74.4) \\
11(25.6)\end{array}$ & 0.385 & $\begin{array}{l}5(45.5) \\
6(54.5)\end{array}$ & $\begin{array}{l}6(60) \\
4(40)\end{array}$ & 0.669 & 0.006 & 0.353 \\
\hline $\begin{array}{l}\text { Breastfeeding (months), } \\
\text { median (range) }\end{array}$ & $5(0-60)$ & $4(0-36)$ & 0.603 & $12(0-54)$ & $8.5(0-19)$ & 0.748 & 0.076 & 0.400 \\
\hline $\begin{array}{r}\text { previous or current } \\
(\# 6) \text { no }\end{array}$ & $\begin{array}{l}74(53.2) \\
65(46.8)\end{array}$ & $\begin{array}{l}20(46.5) \\
23(53.5)\end{array}$ & 0.440 & $\begin{array}{l}8(72.7) \\
3(27.3)\end{array}$ & $\begin{array}{l}3(30) \\
7(70)\end{array}$ & 0.086 & 0.949 & 0.158 \\
\hline Night shift work*: & $\begin{array}{l}22(15.8) \\
117(84.2)\end{array}$ & $\begin{array}{l}7(16.3) \\
36(83.7)\end{array}$ & 0.943 & $\begin{array}{l}1(9.1) \\
10(90.9)\end{array}$ & $\begin{array}{l}1(10) \\
9(90)\end{array}$ & 1 & 0.748 & 0.966 \\
\hline $\begin{array}{l}\text { Alcohol consumption, } \mathrm{n}(\%) \text { : } \\
\text { moderate/heavy } \\
(\# 87) \text { occasional/no }\end{array}$ & $\begin{array}{l}25(18) \\
114(82)\end{array}$ & $\begin{array}{l}0 \\
43(100)\end{array}$ & $<0.05$ & $\begin{array}{l}1(9.1) \\
10(90.9)\end{array}$ & $\begin{array}{l}1(10) \\
9(90)\end{array}$ & 1 & 0.746 & $<0.05$ \\
\hline $\begin{array}{ll}\text { Obesity }\left(\mathrm{BMI}, \mathrm{kg} / \mathrm{m}^{2}\right), \mathrm{n}(\%): & \geq 30 \\
& <30\end{array}$ & \begin{tabular}{|l|}
$25(18)$ \\
$114(82)$
\end{tabular} & $\begin{array}{l}14(32.6) \\
29(67.4)\end{array}$ & 0.042 & \begin{tabular}{|l|}
$1(9.1)$ \\
$10(90.9)$
\end{tabular} & $\begin{array}{l}2(20) \\
8(80)\end{array}$ & 0.587 & 0.577 & 0.047 \\
\hline $\begin{array}{r}\text { Higher education (>high school): yes } \\
\text { (\# 6) no }\end{array}$ & $\begin{array}{l}60(43.2) \\
79(56.8)\end{array}$ & $\begin{array}{l}6(14) \\
37(86)\end{array}$ & $<0.001$ & $\begin{array}{l}6(54.5) \\
5(45.5)\end{array}$ & $\begin{array}{l}3(30) \\
7(70)\end{array}$ & 0.387 & 0.553 & $<0.001$ \\
\hline $\begin{array}{lr}>10 \text { chest radiologic imaging: } & \text { yes } \\
\text { no }\end{array}$ & $\begin{array}{l}37(26.6) \\
102(73.4)\end{array}$ & $\begin{array}{l}9(20.9) \\
34(79.1)\end{array}$ & 0.453 & \begin{tabular}{|l|}
0 \\
$11(100)$
\end{tabular} & $\begin{array}{l}2(20) \\
8(80)\end{array}$ & 0.214 & 0.172 & 0.564 \\
\hline $\begin{array}{r}\text { Breast or ovary cancer in relatives }{ }^{*} \text { yes } \\
\text { yes no }\end{array}$ & $\begin{array}{l}49(35.3) \\
90(64.7)\end{array}$ & $\begin{array}{l}14(32.6) \\
29(67.4)\end{array}$ & 0.745 & $\begin{array}{l}2(18.2) \\
9(81.8)\end{array}$ & $\begin{array}{l}2(20) \\
8(80)\end{array}$ & 1 & 0.220 & 0.611 \\
\hline Other breast cancers & 0 & $1(2.3)$ & - & 0 & 0 & - & - & - \\
\hline Breast benign lesions (yes/no) & $8(5.8) / 131$ & $2(4.7) / 41$ & 1 & $2(\mathbf{1 8 . 2}) / 9$ & $0 / 11$ & 0.476 & 0.358 & 0.735 \\
\hline Gynecological cancers & $3(2.2)$ & 0 & - & 0 & 0 & - & - & - \\
\hline Gynecological benign lesions & $35(25.2)$ & $12(27.9)$ & 0.721 & $5(45.5) / 6$ & $2(20) / 8$ & 0.362 & 0.460 & 0.971 \\
\hline Other cancers & $3(2.2)$ & $1(2.3)$ & - & 0 & $1(10)$ & - & - & - \\
\hline Other benign lesions (yes/no) & $11(7.9) / 128$ & $0 / 43$ & 0.069 & $1(9.1)$ & $1(10)$ & - & 0.629 & 0.191 \\
\hline $\begin{array}{l}\text { Other cancers in relatives: } \begin{array}{r}\text { yes } \\
(\# 4) \text { no }\end{array} \\
\end{array}$ & $\begin{array}{l}90(64.7) \\
49(35.3) \\
\end{array}$ & $\begin{array}{l}22(51.2) \\
21(48.8) \\
\end{array}$ & 0.109 & $\begin{array}{l}8(72.7) \\
3(27.3) \\
\end{array}$ & $\begin{array}{l}6(60) \\
4(40) \\
\end{array}$ & 0.659 & 0.646 & 0.106 \\
\hline
\end{tabular}

\# Number of patients with no response to question; \#\# 91 (65.5\%) patients from the City of Zagreb; ${ }^{*}$ Including 3 women with only HRT use $<5$ y. but with $\geq 5$ years total use of both HRT and contraception; Abbreviations: BMI=body mass index, HRT=hormone replacement therapy, TNM=tumor/node/metastasis 
birth for the first time, by about $7 \%$ per any subsequent birth (21), and by $4.3 \%$ per cumulative year of breastfeeding (22). Alcohol consumption and smoking are known BCa risks and IARC classified agents $(3,8,23)$, and we observed some spatial differences with women from urban area smoking more often and in urban continental area having higher alcohol consumption, which was comparable to the previous study (11).

Other modifiable risk factors include physical activity, weight gain (24), diet (25), however, population attributable risks differ somewhat by menopause status; obesity being the risk only for postmenopausal women (26). Certain additional factors were also associated with increased $\mathrm{BCa}$ risk such as breast density, height (27), higher level of education (associated with parity and socioeconomic status) (25). Importance of environmental factors for $\mathrm{BCa}$ was highlighted by the study investigating pairs of twins showing that only $27 \%$ of the BCa risk may be explained by heritable factors (28). Furthermore, one previous study showed that elevated breast cancer incidence rate can be completely attributed to the regional differences in known BCa risk factors (29).

While the difference between BCa diagnosis in earlier stage between the continental and the Mediterranean Croatia was not statistically significant $(\mathrm{P}=0.086)$, the possibility of a certain degree of selection bias cannot be excluded. This may be due to a lower number of women hospitalized from the Mediterranean region (mostly the northern part), which were also diagnosed at younger age. Therefore, certain degree of selection bias could be caused by choice of younger patients from the Mediterranean area for treatment at the University Hospital for Tumors, the largest national hospital specialized for treatment of tumors, and located in the Croatian capital.

We also noted apparent differences in genetic factors as it appears that higher proportion of women living in the continental part of the country reported breast or ovary cancer in their relatives, however this was not statistically significant in this sample size. This trend was also noted for premenopausal women, the majority of them being from the continental and urban parts. Furthermore, patients living in urban settlements from both main regions reported other cancers in their relatives somewhat more often. A degree of possible contribution of specific spatial cumulative environmental exposures to these genetic factors differences could not be estimated. These findings could be by chance or influenced by higher access to cancer education and screening programs in urban areas with no need to travel great distances to receive care (12). It is thus unclear in which degree observed trend for genetic factors differences represent true finding, as genetic mutations status of included patients and their relatives is not known. However, presence of the same finding in premenopausal women could point to inherited mutations and hence $\mathrm{BCa}$ occurrence in younger age, or they could possibly be influenced by higher cancer awareness in the younger premenopausal women.

Strengths of our study include detailed personal and family medical history data, inclusion of both premenopausal and postmenopausal women, and epidemiologically representative sample by number of new BCa cases $(\sim 8 \%)$ per year, and by surveying patients from all parts of Croatia. Since significant number of included patients were from the City of Zagreb, this corresponds to the high proportion of those patients in yearly incidence of BCa (13).

Limitations of this study are collection of data by self-administered questionnaire which could be susceptible to underreporting of some $\mathrm{BCa}$ risk factors, regarding either medications or health conditions. The number of included patients from the Mediterranean area was lower than of those from the continental Croatia, and certain selection bias of those choosing the treatment in Zagreb could not be excluded, hampering firmer conclusions for this region. Relatively lower total sample size also contributes to these difficulties. Additionally, we collected data on place of current residence and not on duration of living in the area, hence certain bias is possible regarding duration and level of exposure to some environmental risk factor(s) typical for a region.

\section{CONCLUSIONS}

Several regional and urban/rural BCa risk factors variations characteristical for lifestyle differences were noticed in total breast cancer Croatian population sample. This conclusion was supported by generation differences found between premenopausal younger and postmenopausal old- 
er women pointing to similar environmental factors. However some trend for genetic background divergences was also observed.

\section{Acknowledgements}

We are grateful to all the women diagnosed with breast cancer that participated in this research in their difficult life moments. We would also like to thank other hospital healthcare professionals at Department of Surgery in University Hospital for Tumors, Zagreb, Croatia.

\section{Funding and declaration of interest}

This academic research was carried out without any conflict of interest. This study was funded by the corresponding author.

\section{REFERENCES}

1. Kelava I, Tomičić K, Kokić M, Ćorušić A, Planinić $\mathrm{P}$, Kirac I, et al. Breast and gynecological cancers in Croatia, 1988-2008. Croat Med J. 2012;53(2):100-8.

2. International Agency for Research on Cancer. IARC Monographs on the evaluation of carcinogenic risks to humans - List of classifications by cancer site. 2015 [Accessed 01.12.2018.]. Available from: http://monographs.iarc.fr/ENG/Classification/index.php.

3. International Agency for Research on Cancer. IARC Monographs on the evaluation of carcinogenic risks to humans - Alcohol Consumption and Ethyl Carbamate; Volume 96. 2010 [Accessed 01.12.2018.]. Available from: http://monographs.iarc.fr/ENG/Monographs/ vol96/mono96.pdf.

4. International Agency for Research on Cancer. IARC Monographs on the evaluation of carcinogenic risks to humans - Pharmaceuticals; Volume 100A. 2012 [Accessed 01.12.2018.]. Available from: http://monographs iarc.fr/ENG/Monographs/vol100A/mono100A.pdf.

5. International Agency for Research on Cancer. IARC Monographs on the evaluation of carcinogenic risks to humans - Radiation; Volume 100D. 2012 [Accessed 01.12.2018.]. Available from: http://monographs.iarc. fr/ENG/Monographs/vol100D/mono100D.pdf.

6. International Agency for Research on Cancer. IARC Monographs on the evaluation of carcinogenic risks to humans - Polychlorinated biphenyls and polybrominated biphenyls; Volume 107. 2016 [Accessed 01.12. 2018.]. Available from: http://monographs.iarc.fr/ ENG/Monographs/vol107/mono107.pdf.

7. International Agency for Research on Cancer. IARC Monographs on the evaluation of carcinogenic risks to humans - Painting, Firefighting, and Shiftwork; Volume 98. 2010 [Accessed 01.12.2018.]. Available from: http://monographs.iarc.fr/ENG/Monographs/vol98/ mono98.pdf.
8. International Agency for Research on Cancer. IARC Monographs on the evaluation of carcinogenic risks to humans - Personal Habits and Indoor Combustions; Volume 100E. 2012 [Accessed 01.12.2018.]. Available from: http://monographs.iarc.fr/ENG/Monographs/ vol100E/mono100E.pdf.

9. Singletary SE. Rating the Risk Factors for Breast Cancer. Ann Surg. 2003;237(4):474-82.

10. World Cancer Research Fund/American Institute for Cancer Research. Continuous Update Project Expert Report 2018. Diet, nutrition, physical activity and breast cancer 2018 [Accessed 01.12.2018.]. Available from: dietandcancerreport.org.

11. Kern J, Strnad M, Coric T, Vuletic S. Cardiovascular risk factors in Croatia: struggling to provide the evidence for developing policy recommendations. BMJ. 2005;331(7510):208-10.

12. Stamenić V, Strnad M. Urban-rural differences in a population-based breast cancer screening program in Croatia. Croat Med J. 2011;52(1):76-86.

13. Croatian Institute of Public Health. Croatian National Cancer Registry. Cancer incidence in Croatia 2015. Bulletin No 40 [Internet]. 2018 [Accessed 01.12.2018.]. Available from: https://www.hzjz.hr/wp-content/uploads/2018/03/Bilten_2015_rak_final.pdf.

14. Croatian Bureau of Statistics. National Classification of Spatial Units for Statistics 2012 (NKPJS 2012)2012; NN 96/2012 [Accessed 01.12.2018.]. Available from: https://narodne-novine.nn.hr/clanci/sluzbeni/2012_08 _96_2161.html.

15. Croatian Bureau of Statistics. The Model for the Differentiation of Urban, Rural and Semi-Urban Settlements in the Republic of Croatia. Methodological Guidelines 67 [Internet]. 2011 [Accessed 01.12.2018.]. Available from: https://www.dzs.hr/eng/Publication/ metodologije/metod_67.pdf.

16. Croatian Bureau of Statistics. Census of Population, Households and Dwellings 2011, First Results by Settlements. Statistical Reports; 1441 [Internet]. 2011 [Accessed 01.12.2018.]. Available from: https://www.dzs. hr/Hrv_Eng/publication/2011/SI-1441.pdf.

17. Stangroom J. Calculators. Social Science Statistics [cited 2018 24th and 25th November]. [software]. Available from: https://www.socscistatistics.com/tests/Default.aspx.

18. Collaborative Group on Hormonal Factors in Breast Cancer. Breast cancer and hormonal contraceptives: collaborative reanalysis of individual data on 53297 women with breast cancer and 100239 women without breast cancer from 54 epidemiological studies. Lancet. 1996;347(9017):1713-27.

19. Key TJ, Appleby PN, Reeves GK, Travis RC, Alberg AJ, Barricarte A, et al. Sex hormones and risk of breast cancer in premenopausal women: a collaborative reanalysis of individual participant data from seven prospective studies. Lancet Oncol. 2013;14(10):1009-19. 
20. Key T, Appleby P, Barnes I, Reeves G. Endogenous sex hormones and breast cancer in postmenopausal women: reanalysis of nine prospective studies. J Natl Cancer Inst. 2002;94(8):606-16.

21. Cuzick J. Assessing risk for breast cancer. Breast Cancer Res. 2008;10(Suppl 4):S13.

22. Collaborative Group on Hormonal Factors in Breast Cancer. Breast cancer and breastfeeding: collaborative reanalysis of individual data from 47 epidemiological studies in 30 countries, including 50302 women with breast cancer and 96973 women without the disease. Lancet. 2002;360(9328):187-95.

23. Collaborative Group on Hormonal Factors in Breast Cancer. Alcohol, tobacco and breast cancer - collaborative reanalysis of individual data from 53 epidemiological studies, including 58515 women with breast cancer and 95067 women without the disease. Br J Cancer. 2002;87(11):1234-45.

24. Sprague BL, Trentham-Dietz A, Egan KM, Titus-Ernstoff L, Hampton JM, Newcomb PA. Proportion of Invasive Breast Cancer Attributable to Risk Factors Modifiable after Menopause. Am J Epidemiol. 2008;168(4): 404-11.

25. Dartois L, Fagherazzi G, Baglietto L, Boutron-Ruault M-C, Delaloge S, Mesrine S, et al. Proportion of premenopausal and postmenopausal breast cancers attributable to known risk factors: Estimates from the E3N-EPIC cohort. Int J Cancer. 2016;138(10):2415-27.
26. Neuhouser ML, Aragaki AK, Prentice RL, Manson JE, Chlebowski R, Carty CL, et al. Overweight, Obesity, and Postmenopausal Invasive Breast Cancer Risk: A Secondary Analysis of the Women's Health Initiative Randomized Clinical Trials. JAMA Oncol. 2015;1(5): 611-21.

27. Kluttig A, Schmidt-Pokrzywniak A. Established and Suspected Risk Factors in Breast Cancer Aetiology. Breast Care. 2009;4(2):82-7.

28. Lichtenstein P, Holm NV, Verkasalo PK, Iliadou A, Kaprio J, Koskenvuo M, et al. Environmental and heritable factors in the causation of cancer--analyses of cohorts of twins from Sweden, Denmark, and Finland. N Engl J Med. 2000;343(2):78-85.

29. Robbins AS, Brescianini S, Kelsey JL. Regional differences in known risk factors and the higher incidence of breast cancer in San Francisco. J Natl Cancer Inst. 1997;89(13):960-5.

Corresponding author: Katarina Vučić, Department for Safety and Efficacy Assessment of Medicinal products, Agency for Medicinal Products and Medical Devices, Ksaverska cesta 4, 10000 Zagreb, Croatia. e-mail: katarinavucic@yahoo.com 